\title{
The Relationship of Welfare Levels with Pedagogic Competence of Early Childhood Teachers in Solokanjeruk Bandung
}

\author{
Tya Ardilla ${ }^{*}$, Ocih Setiasih $^{2}$, Rita Mariyana ${ }^{3}$ \\ 1,2,3 Indonesia University of Education \\ *Corresponding author. Email:tyaardilla@student.upi.edu
}

\begin{abstract}
This study aims to determine the relationship between the level of welfare and the pedagogical competence of Early Childhood teachers in Solokanjeruk District, Bandung. The research method in this research is the method of correlation by using the Pearson correlation test. This research was conducted on Early Childhood teachers in Solokanjeruk, Bandung who came from formal and non-formal Early Childhood institutions under the Education Office. The sampling technique used in this study was a saturated sampling technique, which involved all members of the population into the sample. The results of the correlation test in this study were divided into three parts, consist of the relationship between the level of welfare and the pedagogical competence of Early Childhood teachers in general, of formal Early Childhood teachers, and of non-formal Early Childhood teachers. The results of the correlation test show that overall, there is a relationship between the level of welfare of Early Childhood teachers and the pedagogical competence of them with a low relationship category and a positive relationship direction. Then for the teachers of formal Early Childhood, the results of the correlation test show that there is no significant relationship between the level of welfare of formal Early Childhood teachers and the pedagogical competence of formal Early Childhood teachers. Furthermore, for non-formal Early Childhood teachers, the correlation test results show that there is a relationship between the level of welfare of non-formal Early Childhood teachers with the pedagogical competence of non-formal Early Childhood teachers with a low relationship category and a positive relationship direction. Because this research is a quantitative study, it is recommended that further researchers conduct more in-depth similar studies.
\end{abstract}

Keywords: Welfare level, pedagogic competence.

\section{INTRODUCTION}

Early Childhood educators are professionals who have the main task of guiding, fostering and caring for Early Childhood. Professional and competent Early Childhood educators have a very important role in preparing the nation's future generations of quality [1]. The competencies possessed by each teacher will show the quality of the teacher in carrying out the learning process. These competencies consist of pedagogical competence, social competence, personality competence, and professional competence.

The issue of competency for Early Childhood teachers in Indonesia still requires attention from many parties. Research findings [2], [3] shows that Early Childhood teachers in Bandung City as well as in Bangka Regency have not met the ideal competence. This is evidenced by the results of data acquisition obtained from teacher work competency tests in Bandung City on a scale of 1-50, the average score obtained by Early Childhood teachers in Bandung is only 14.42. In addition, the detik.news page also reported that the quality of education in Indonesia at this time is still far from adequate, one of which is because the quality of teachers is still problematic [4]. This is evidenced by the results of the 2015 Early Childhood Teacher Competency Test (UKG), with a national average of only 44.5 where this value is still far below the standard value of 75 .

Of the four teacher competencies, researchers focused on just one competency, in this case, it is pedagogical competence. That of the four teacher competencies, pedagogical competence is the competency that dominates the learning process compared to other competencies [5]. Pedagogic competence is the ability of educators to explore understanding of students, design the implementation of learning to evaluate learning outcomes so that students can develop and actualize the various potentials inherent in themselves. [6]. 
Several studies related to the pedagogical competence of early childhood teachers have been conducted, including research [7] regarding the pedagogic competence of Early Childhood teachers with the ability to evaluate children's development. The findings of this study indicate that there is a significant relationship between pedagogical competence and the ability to evaluate children's development of 0.673 . Other than that [8] has also conducted research on the Teacher Working Group [KKG] in supporting the pedagogical competence of early childhood teachers. According to the findings of the study, teacher working groups have great benefits in increasing teacher pedagogical competence. From the Activities of KKG the teachers can exchange information and knowledge that can add broad insights and new discoveries, especially those related to learning.

"Teacher competence cannot stand alone, but there are several factors that can influence it, including: (1) Educational background, (2) Teaching experience, (3) Learning support facilities, (4) The health condition of teachers, (5) The economic condition or level of teacher welfare, (6) The work ethic and love of teachers for their profession, and (7) Supervision of the principal of teacher performance" [9]. From the seven factors, it can be seen that one of the factors that can affect the teacher competence is the economic condition or level of welfare.

Early Childhood teachers have various levels of welfare, with most of the welfare levels below average, especially for non-PNS teachers appointed by underdeveloped foundations, the wages of these teachers mostly only rely on students [10]. That one of the problems for Early Childhood teachers is the low salary. The results of observations made by researchers in the researchers' immediate environment, nongovernment Early Childhood teacher salaries are still below $30-70 \%$ of the Regional Minimum Wage, there are still Early Childhood teachers who get salaries under Rp. 500,000, - (Five hundred thousand rupiah) per month.

From several phenomena that have been described above, related to the low competence of Early Childhood teachers and the low level of welfare of Early Childhood teachers in Indonesia, it encourages researchers to want to know whether there is a relationship between both of them. From several studies that have been conducted, researchers have also not found any research related to the relationship between the two variables. Therefore, the researchers wanted to further investigate the level of welfare with the pedagogical competence of Early Childhood teachers.

Based on the background to the problems above, the following research questions are formulated: Is there a relationship between the level of welfare and the pedagogical competence of Early Childhood teachers in
Solokanjeruk, Bandung? What is the profile of the level of welfare of early childhood teachers in Solokanjeruk, Bandung? What is the pedagogic competency profile of early childhood teachers in Solokanjeruk, Bandung?

Based on the formulation of the problem, the objectives of this study are as following matters: Knowing the relationship between the level of welfare and the pedagogical competence of Kindergarten Teachers in Solokanjeruk, Bandung. Knowing the profile of the welfare level of early childhood teachers in Solokanjeruk, Bandung. Knowing the pedagogic competency profile of early childhood teachers in Solokanjeruk, Bandung.

\section{METHOD}

The approach used in this research is a quantitative approach using the correlational study method. This method was chosen because it is in accordance with the objective research, that is to determine whether there is a relationship between the level of Early Childhood welfare with the competence of Early Childhood teachers in Solokanjeruk, Bandung.

Correlational studies produce numerical exposure shows that the strong relationship between variables and the direction of the relationship, both positively and negatively [11]. If the score of the teachers for the level of welfare is higher, the competence of the teachers is higher too. It means that the result has the positive correlation relationship. Meanwhile, if the score of the teachers for level of welfare is lower, the competence of the teachers is lower too. It means that the direction has a negative correlation relationship.

The research design used is a simple paradigm model or simple correlation because it is only used by one independent variable, that is the level of Early Childhood teacher welfare. While the dependent variable in this study is the pedagogical competence of Early Childhood teachers.

The population in this study were Early Childhood Education teachers in Solokanjeruk, Bandung who came from thirty-nine institutions under the Education Office. Eight institutions include formal Early Childhood institutions with a total of 29 teachers, and 31 nonformal Early Childhood institutions and the total of 38 teachers. The total number of Early Childhood teachers in Solokanjeruk is 111 people.

The sampling technique used was a saturated sampling technique. Saturated sampling technique is a sampling technique using the entire population, or it can be called a census [11]. This technique was chosen because the population of Early Childhood teachers in Solokanjeruk, Bandung, is only 111 people, where the figure is close to 100 and the entire population can be 
reached by researchers, so the resulting data is more representative.

The assessment instrument used in this study was a questionnaire. The type of instrument used in the questionnaire is a closed instrument. It means that the answer to the questions in the questionnaire have been available, so that the respondent just chooses it.

On the welfare level variable, the instrument used was developed from [12] regarding the factors that influence the level of teacher welfare, including: income, household consumption or expenditure, increased professional skills, and conducive working conditions, safe and comfortable.

The type of questionnaire instrument used in measuring the level of welfare of Early Childhood teachers in Solokanjeruk is a scale questionnaire. The available answers include "Always"; "Often", "Sometimes", "Ever", and "Never".

The pedagogic competency variables of Early Childhood teachers, the instrument used was developed from the Regulation of the Minister of Education and Culture (Permendikbud) no. 137 of 2014 concerning Early Childhood National Standards [13]. The type of instrument used to measure the pedagogical competence of Early Childhood teachers is a multiple-choice test.

The collection of the data in this study was carried out from July 23, 2020 to August 12, 2020, which was carried out in two ways, consisting of online and offline. The distribution of online questionnaires is used by utilizing Google form feature, the link is shared online with Early Childhood teachers in Solokanjeruk, Bandung. Meanwhile, offline data collection was carried out by manually distributing questionnaires to each institution in Solokanjeruk.

In the data analysis process, before conducting a correlation test between the two variables, the data normality test was conducted first. The normality test is intended to determine whether or not the distribution of data or values is normal. If the data is normally distributed, then the statistics used are parametric statistics, but if the data is not normally distributed, the hypothesis is tested using non-parametric statistical techniques. The normality test used in this study is the Kolmogorov Smirnov normality test. The normality test is part of the classical assumption test, where the classical assumption test itself is a statistical requirement that must be met in the regression analysis.

After the data is known and normally distributed, then the correlation test is carried out to determine whether there is a relationship between welfare variables and competence of Early Childhood teachers. This correlation test was carried out by using SPSS version 25. The type of correlation test used in this study is the correlation test.

\section{RESULT AND DISCUSSION}

\subsection{The Relationship Between the Level of Welfare and the Pedagogical Competence of Early Childhood Teachers}

Respondents in this study were the entire population of Early Childhood teachers in Solokanjeruk, Bandung Regency who are under the Education Office, both formal and non-formal Early Childhood institutions. Therefore the results of this study are divided into three parts, namely: the relationship between the level of welfare and the pedagogical competence of formal and non-formal Early Childhood teachers in Solokanjeruk; the relationship between the level of welfare and the pedagogical competence of formal Early Childhood teachers in Solokanjeruk as well as the relationship between the level of welfare and the pedagogical competence of non-formal Early Childhood education teachers in Solokanjeruk.

The results of the Pearson correlation test between the level of welfare and the pedagogical competence of formal and non-formal Early Childhood education teachers in Solokanjeruk District, Bandung Regency using the SPSS version 25 program are as follows: a significance value of $0.000<0.005$ is obtained, which means that $\mathrm{H}_{0}$ is rejected and $\mathrm{H}_{\mathrm{a}}$ is accepted with a positive correlation coefficient of 0.367 .

The value of the coefficient of data determination between the level of welfare and the pedagogical competence of Early Childhood teachers is as follows:

$$
\begin{aligned}
\mathrm{KD} & =\mathrm{r}^{2} \times 100 \% \\
& =[0,367]^{2} \times 100 \% \\
& =0,1347 \times 100 \% \\
& =13,47 \%
\end{aligned}
$$

Based on the results of the research, the correlation test between the level of welfare and pedagogic competence on 111 early childhood teacher respondents in Solokanjeruk District as a whole shows a significant relationship, with a correlation coefficient of 0.367 . This shows that the level of early childhood teacher welfare affects or contributes to the pedagogical competence of early childhood teachers.

The value of the Pearson correlation in this study was 0.367 . The degree of correlation in this study falls into the weak or low category. This means that the level of relationship between the level of welfare and the pedagogical competence of early childhood teachers is in the low category.

In addition, to determine the relationship between the two variables, a coefficient of determination analysis was also carried out. As has been described in the research results. The coefficient of determination in this 
study was $13.47 \%$, this means that the pedagogical competence of early childhood teachers is influenced by the welfare level of early childhood teachers of $13.47 \%$ and $86.53 \%$ is influenced by other variables which are not studied.

The value of the Pearson correlation can be a guide whether the correlation has a positive or negative direction [14]. If it has a positive direction, it means that the variable $\mathrm{Y}$ increases if the variable $\mathrm{X}$ also increases. If it has a negative direction, it means that variable $Y$ increases if variable $\mathrm{X}$ decreases or otherwise. The value of the Pearson correlation in this study is positive, this means that the variable level of early childhood teacher welfare is positively related to the pedagogical competence of early childhood teachers. Which means that the variable level of early childhood teacher welfare can increase if the welfare level of early childhood teachers increases too.

From these results it can be concluded that in order to improve the pedagogical competence of early childhood teachers, one of the efforts that can be done is to increase the level of welfare.

Then for formal early childhood teachers, the results of the Pearson correlation test on formal early childhood teachers in Solokanjeruk, Bandung are follows: The significance value is $0.006>0.005$, then $\mathrm{H} 0$ is accepted and $\mathrm{Ha}$ is rejected, it means that there is no significant relationship between the level of early childhood teacher welfare with the pedagogical competence of formal early childhood teachers in Solokanjeruk, Bandung.

Based on the research results, the correlation test between the level of welfare and the pedagogical competence of 29 formal early childhood teacher respondents in Solokanjeruk shows that there is no significant relationship between the level of teacher welfare and the pedagogical competence of formal early childhood teachers in Solokanjeruk, Bandung.

The absence of a correlation between the level of welfare and the pedagogical competence of formal early childhood teachers in Solokanjeruk is probably because there are other factors outside the level of welfare that can affect pedagogical competence. However, in this study the researcher did not examine the relationship of other factors beyond the level of welfare to the pedagogic competence of formal Early Childhood teachers.

Furthermore, for non-formal early childhood teachers, the results of the Pearson correlation test on non-formal early childhood teachers in Solokanjeruk, Bandung are as follows: the significance value is exactly 0.005 . If the significance value is right at 0.005 , then to find out whether there is a relationship or not the two variables are to compare the Pearson Correlation with $r$ table. If Pearson Correlation> $r$ table then the two variables are related, and if Pearson Correlation $<\mathrm{r}$ table then the two variables are not related

In the distribution of the $r$ value table, there is no $r$ table value for $\mathrm{N}=82$, then look for the value of $\mathrm{r}$ table with $\mathrm{N}$ that is close to 82 . In this case the researcher takes the $r$ table for $\mathrm{N}=80$, is 0.220 . The significance value of the correlation test for the variable level of welfare with the competence of non-formal early childhood education teachers in Solokanjeruk is 0.309.

Then the decision making: $0.309>0.220$ [there is a significant relationship between the level of welfare and the competence of non-formal early childhood teachers in Solokanjeruk, Bandung.

The value of the coefficient of the data determination between the level of welfare and the pedagogical competence of non-formal early childhood teachers is following matters:

$$
\begin{aligned}
\mathrm{KD} & =\mathrm{r}^{2} \times 100 \% \\
& =[0,309]^{2} \times 100 \% \\
& =0,095 \times 100 \% \\
& =9,55 \%
\end{aligned}
$$

The value of the Pearson correlation in this study was 0.309 . The degree of correlation in this study falls into the weak or low category. This means that the level of relationship between the level of welfare and the pedagogical competence of early childhood teachers is in the low category.

In addition, to determine the relationship between the two variables, a coefficient of determination analysis was also carried out. As has been described in the research results. The coefficient of determination in this study was $9.55 \%$, this means that the pedagogical competence of early childhood teachers is influenced by the level of Early Childhood teachers' welfare of $9.55 \%$ and $90.45 \%$ is influenced by other variables not examined.

The value of the Pearson correlation can be a guide whether the correlation has a positive or negative direction [14]. If it has a positive direction, it means that the variable $\mathrm{Y}$ increases when the variable $\mathrm{X}$ increases too. If it has a negative direction, it means that variable $\mathrm{Y}$ increases when variable $\mathrm{X}$ decreases or vice versa. The value of the Pearson correlation in this study is positive, this means that the variable level of early childhood teacher welfare is positively related to the pedagogical competence of early childhood teachers. Which means that the variable level of early childhood teacher welfare can increase if the welfare level of early childhood teachers is increased too.

From these results it can be concluded that in order to improve the pedagogical competence of non-formal 
early childhood teachers, one of the efforts that can be done is to increase the level of welfare.

\subsection{Welfare Level Profile of Early Childhood Teachers}

For the profile of the early childhood teachers as a whole welfare level, based on the results of research on 111 early childhood teachers in Solokanjeruk District, it was found that as many as 4 teachers $(3.60 \%)$ had the level of welfare in the high category, while as many as 68 teachers $(61.26 \%)$ are in the medium category, and as many as 39 teachers (35.14\%) are in the low category.

Then for the level of welfare of formal early childhood teachers, based on the results of research on 29 formal early childhood teachers in Solokanjeruk, it was found that the welfare level of formal early childhood teachers in Solokanjeruk who was in the highest category was 1 person $(3.45 \%)$, who were in the medium category as many as 1 person (3.45\%). 21 teachers $(72.41 \%)$, and 7 teachers $(24.14 \%)$ are in the low category. This is described in table 5 below:

Furthermore, for the welfare level of non-formal early childhood teachers, based on the results of research on 82 non-formal early childhood teachers in Solokanjeruk, it was found that the welfare level of nonformal early childhood teachers in Solokanjeruk who was in the high category was 3 people $(3.66 \%)$, who were at There were 46 people in the moderate category $(56.10 \%)$, and in the low category there were 30 people $(40.24 \%)$

From the three results of the data analysis, the results obtained were not much different. The highest percentage of the three is in the medium category, then in the low category, and the least percentage is in the high category. This means that almost all early childhood teachers in Solokanjeruk have their welfare level in the middle to lower category. This means that most of the basic needs of early childhood teachers in Solokanjeruk have not been fully fulfilled.

However, between formal and non-formal Early Childhood teachers in Solokanjeruk, the results of the data analysis show that non-formal early childhood teachers have a lower level of welfare when compared to formal early childhood teachers. This is indicated by the percentage of the low welfare level category for non-formal early childhood teachers, which is higher at $40.24 \%$ compared to formal early childhood teachers with a percentage of $24.11 \%$.

In relation to the profile of the welfare level, it can be concluded that the welfare level of early childhood teachers in Solokanjeruk is in the middle to lower category.

\subsection{Pedagogic Competency Profile for Early Childhood Teachers}

For the pedagogical competency profile of early childhood education teachers as a whole, based on the results of research on 111 early childhood teachers in Solokanjeruk District, it was found that 27 people $(24.32 \%)$ of the pedagogical competence of early childhood teachers in Solokanjeruk were in the high category, 65 people $(58.56 \%)$ are in the medium category, and 19 people $(17.12 \%)$ are in the low category.

Then for the pedagogical competence of formal early childhood teachers, based on the results of research on 29 formal early childhood teachers in Solokanjeruk, it was found that 13 people $(44.83 \%)$ of the pedagogical competence of early childhood teachers in Solokanjeruk were in the high category, 14 people $(48.27 \%)$ were in the medium category, and 2 people $(6.90 \%)$ are in the low category.

Furthermore, for the pedagogical competence of non-formal early childhood teachers, based on the results of research on 82 non-formal Early Childhood teachers in Solokanjeruk, it was found that 14 people (17, 07\%) of the pedagogical competence of early childhood teachers in Solokanjeruk were in the high category, 51 people $(62.20 \%])$ are in the medium category, and 17 people $(20.73 \%)$ are in the low category.

From the three results of data analysis, it shows that the overall pedagogical competence of early childhood teachers is in the medium category. This is evidenced by the largest percentage of the three data analysis results in the medium category. This is in accordance with the results of research [15] concerning the description of early childhood pedagogical competence, he stated that the pedagogical competence of early childhood teachers is quite good, for that early childhood teachers need to continue to strive to improve their pedagogical competence.

However, between formal and non-formal early childhood teachers, when compared to their pedagogical competence, the results of the data analysis show that there are differences, namely the percentage of formal early childhood teachers who have high category pedagogic competences compared to non-formal early childhood teachers, on the other hand, non-formal early childhood teachers who have more low category pedagogical competencies when compared to nonformal early childhood teachers. This means that nonformal early childhood teachers have lower pedagogical competence when compared to formal early childhood teachers.

Regarding the pedagogical competency profile, it can be concluded that the pedagogic competence of 
Early Childhood teachers in Solokanjeruk is in the medium category, and when compared between formal and non-formal early childhood teachers, non-formal early childhood teachers have lower pedagogical competencies when compared to formal early childhood teachers. Therefore, all early childhood teachers, both formal and non-formal early childhood teachers, need to continue to improve their pedagogical competence.

\section{CONCLUSION}

Based on the result of the research, it can be concluded that overall, there is a relationship between the level of welfare and the pedagogical competence of early childhood teachers in Solokanjeruk, Bandung Regency with a low relationship category and has a positive direction.

The profile of the level of welfare of early childhood teachers in Solokanjeruk, Bandung is in the medium category, with the welfare level of formal early childhood teachers being higher than non-formal early childhood teachers.

The pedagogic competency profile of early childhood teachers in Solokanjeruk, Bandung as a whole is in the moderate category, with the pedagogic competence of formal early childhood teachers being higher than the pedagogic competences of non-formal early childhood teachers.

\section{REFERENCES}

[1] Yuslam Y, Setiani RE, Sari AK. Studi tentang kompetensi guru paud berkualifikasi akademik sarjana PG-PAUD dan NonPG-PAUD di PAUD Istiqomah Sambas Purbalingga. Al-Athfal: Jurnal Pendidikan Anak. 2017;3(2):151-68. Available from: https://doi.org/10.1007/BFb0025774.

[2] Faridah I, Kurniady DA. Kompetensi kerja guru, kepemimpinan pembelajaran dan kinerja mengajar guru TK kota Bandung. Jurnal Administrasi Pendidikan. 2015;22(2).58-68.

[3] Susanti BH. Kontribusi kompetensi kerja guru dan iklim sekolah terhadap kinerja mengajar guru Taman Kanak Kanak. Jurnal Administrasi Pendidikan. 2014;21(2):107-14.

[4] Yunus S. Mengkritisi kompetensi guru [Internet]. Detiknews.com. 2017[Cited 2020 Nov 24]. Available from: https://news.detik.com/kolom/d3741162/mengkritisi-kompetensi-guru.

[5] Safitri DP, Khaerudin, Ariani D. Eilable evaluasi kompetensi pedagogik guru pasca pelatihan guru pembelajar moda daring. Jurnal Pembelajaran Inovtif. 2018;1(159):33-6.
[6] Payong MR. Sertifikasi profesi guru konsep dasar. Problematika dan implementasinya. Jakarta: PT Indeks; 2011.

[7] Safitri DP. Evaluasi kompetensi pedagogik guru pasca pelatihan guru pembelajar moda daring untuk guru SD kelas bawah di P4TK bisnis dan pariwisata. Sawangan [Doctoral dissertation, Universitas Negri Jakarta]. Jakarta: UNJ; 2018.

[8] Nurhikmah I, Widyasari W, Sya MF. Peran kelompok kerja guru (KKG) dalam meningkatkan kompetensi pedagogik guru. E-Journal Skripsi: Fakultas Keguruan dan Ilmu Pendidikan. 2019 Apr 12;2(2). Available from: https://unida.ac.id/ojs/ skripsiunida/article/view/1666/1340.

[9] Djamarah. Psikologi belajar. Jakarta: Rineka Cipta, 2008.

[10] Puspitarani P, Masykur AM. Makna menjadi guru taman kanak-kanak (Sebuah Studi Kualitatif Fenomenologis). Empati. 2018 Mar 28;7(1):30814.

[11] Sugiyono. Metode penelitian pendidikan (Pendekatan kuantitatif, kualitatif, $\mathrm{R}$ dan D). Bandung: Alfabeta; 2012.

[12] Suparlan. Menjadi guru efektif. Yogyakarta: Hikayat; 2005.

[13] Peraturan Menteri Pendidikan dan Kebudayaan Republik Indonesia Nomor 137 Tahun 2014 tentang Standar Nasional Pendidikan Anak Usia Dini. 2014.

[14] Nugroho S, Akbar S, Vusvitasari R. Kajian hubungan koefisien korelasi pearson (r), spearmanrho, kendall-Tau, Gamma (G), dan somers. gradien: Jurnal Ilmiah MIPA. 2008;4(2):372-81.

[15] Fitria N. Gambaran kompetensi pedagogik guru PAUD. In Prosiding Seminar Nasional Pendidikan FKIP. 2017 May 30;1(2):231-40. 